УДК 6:539.2-022.532

\title{
THE INFLUENCE OF MORPHOLOGY, CONDITIONS OF PRODUCTION AND EXTERNAL EFFECTS ON NANOPARTICLES' (IN TERMS OF IRON) DIELECTRIC PROPERTIES
}

\author{
D. I. Bilenko', D. V. Terin ${ }^{1}$, 0. Tozkoparan² ${ }^{2}$ 0. Yildirim², \\ V. V. Galushka' ${ }^{1}$ I. Dincer ${ }^{2}$, E. K. Dobrinskii ${ }^{3}$, Y. Elerman' ${ }^{2}$, S. B.Venig ${ }^{1}$ \\ ${ }^{1}$ Saratov State University, Russia \\ ${ }^{2}$ Ankara University, Turkey \\ ${ }^{3}$ State Research Institute for Chemistry and Technology \\ of Organoelement Compounds, Saratov, Russia \\ E-mail: lab32@mail.ru
}

It was shown that the complex research of iron nanoparticles properties by different methods, supplemented each other, permit to receive the data about the interior sizes of nanoparticles, a number of physical properties of particles, their dependence on frequency and changes produced by various influences. It was found that the conductivity of nanoparticles changed under the square dependence $\sigma=\sigma_{0} \omega_{2}$.

Key words: nanoparticles, core-shell parameters, iron nanoparticles properties, real and imaginary dielectric permittivity and conductivity, SEM, EDX.

Влияние морфологии, условий получения и внешних воздействий на диэлектрические свойства наночастиц на основе железа

Д. И. Биленко ${ }^{1}$, Д. В. Терин ${ }^{1}$, О. Тозкопаран², О. Йлдырым ${ }^{3}$, В. В. Галушка', И. Динкер ${ }^{2}$, Э. К. Добринский ${ }^{3}$, Я. Элерман ${ }^{2}$, С. Б. Вениг ${ }^{1}$

${ }^{1}$ Саратовский государственный университет

${ }^{2}$ Анкарский университет, Турция

ЗГосударственный научно-исследовательский институт химии и технологии элементоорганических соединений, Саратов E-mail: lab32@mail.ru

Комплексное исследование свойств наночастиц железа различными дополняющими друг друга методами позволило получить данные о внутренних размерах, диэлектрических и физических свойствах наночастиц и их зависимости от частоты и изменений, производимых с помощью различных воздействий. Обнаружено, что проводимость наночастиц железа имеет квадратичную частотную зависимость $-\sigma=\sigma_{0} \omega_{2}$.

Ключевые слова: наночастицы, параметры ядро-оболочка, свойства наночастиц на основе железа, действительные и мнимые части диэлектрической проницаемости и проводимости, сканирующая электронная микроскопия, энергодисперсионный анализ.

\section{Introduction}

In recent years research of different production methods of nanomaterials and investigation of their properties causes a great interest $[1,2]$. Thanks to specific properties of superdispersed powders such as significant contribution of surface properties, internal stress, peculiar magnetic characteristics, appearing due to similar structure; size factor, defining a higher level of extra energy; high catalyst properties - those materials can find a great amount of potential application in metal manufacture, electronics, biological, chemical and pharmaceutical industries [3-12].

The gap between the opportunities of creating objects and the abilities of getting knowledge about their properties and data of nanoparticles is widening. This gap is becoming an inhibitive factor in nanostructure research and more over in their practical application. To our opinion we should mention some specific applications that characterize the breadth and range of this problem.

To reach electromagnetic compatibility in aircraft special materials absorbing electromagnetic radiation are used; and one of extenders used in absorbers is superdisperced and powder carbonyl iron [3]. Magnetopolymer composition of micro- or/ and nanosize, distributed in highly elastic polymeric matrix, having the ability to deform to hundreds percent under the action of external magnetic field are widely used [4].

Wide-range research showed high efficiency of iron nanopowders application in plant cultivation, animal husbandry, poultry farming, fishery and in feeding stuff [5]. It is stated that application of aqueous suspension on the basis of nano crystal iron promotes the immunological index adjustment of animals infected with a virus just a like the man's T-cell leukemia. Stimulating effect is obvious in seeds germinability $[6,7]$. Great interest is arising out of developing and perfecting the

() Бипенко Д. П., Терин Д. В., Тозкопаран О., Йлдырым О., Галушка В. В., Динкер П., Добринский Э. К. , ЭперманЯ., Вениг С. Б., 2015 
methods of magnetic nanoparticles (in the terms of iron) production. They might serve as target drug carrier in chemotherapy [8]. Not less important seems the problem of predicting and evaluating of the future probable influence of new materials on a man's health and the environment, so the task is to develop new appropriate security standards. Nanoparticles can penetrate unchangeable through blood-brain barrier and cumulate in organs and tissues, toxicity of nanoparticles is defined by their shape and size [9].

The problem of nanoparticles' diagnosis is in their instability, high reactivity and internal inhomogeneity. Nowadays there is no common method or complex of methods in scientific literature for multiparametric investigation, calibration and classification of nanoparicles.

The problem of identification the form, structure, size and the character of size distribution, structure and inner properties of nanoparticles and also their static and dynamic, electric and magnetic properties is thought to be fundamental. The solution of those tasks is determined by the field of superdispersed powders application.

One of the informative ways getting these data is the research of frequency dependences of complex dielectric and magnetic permeability, which are the basis to multivariate multiparametric investigation of nanoparticles. Those investigations are necessary to establish the correlation between their properties and the effectiveness of application in different fields. The aim of this work is a complex research of iron nanoparticles properties.

\section{Samples and production methods}

Some dozens methods of NP production are known nowadays. There are three kinds of methods that are of great interest from technological point of view. They are mechanical method, chemical and plasma ones. To get the investigated materials we used the reactor $25 \mathrm{~kW}$. Plasma reactor is the electroarc evaporator-condenser with stabilized plasma flow. Gas system permitted to delete moisture and oxygen, imported with the stuff and when the apparatus was opened, from technological gas. The system was hermetically assembled and vacuumized up to residual pressure $0.05 \mathrm{~kg} / \mathrm{cm}^{2}$ and filled in with inert gas-argon up to pressure $1.2 \mathrm{~kg} / \mathrm{sm}^{2}$. Electric arc was burned up between the electrodes of reactor and under the influence of stabilizing (vortical) technological stream it localized in the centre of the reactor. The stuff of the powder had physicochemical composition: carbon 0.6-0.8; nitrogen $0.5-0.8$; oxygen $0.8-1.2$; iron $98.10-97.20$ (fraction of total mass, \%).

The average diameter of spherical stuff particles was $2.2 \mu \mathrm{m}$. The delivery of raw material was performed with pneumotransport method. The produced aerosol proceeded into the electric arc zone and the particles are exposured by 5000-6000 K plasma discharge. Gas-vapor stream with evaporated material were mixed with hardening and stabilizing gas on the output from the reactionary zone and was cooled up to temperature $50-60^{\circ} \mathrm{C}$. Then separation of large-scale fraction from nanopowder was done. The nanopowder collected on the filter was put into the storage filled in with inert gas. This method permits to produce powders of narrow fractional composition. Large surface of material contact with plasma increases the effectiveness and rises the process efficiency. Specific surface area of producted iron nanopowder was determined by the method of nitrogen thermal desorption.

\section{Scanning electron microscopy (SEM)}

To investigate the morphology characteristics with the help of scanning electron microscopy the samples were subjected to preliminary preparation. SEM images were got just by simply pilling the powder or by monitoring the pressed pills. Material consumption for one pill $3 \mathrm{~mm}$ diameter was from 40 to $200 \mu \mathrm{gm}$. The pressure of forming pills variated from 500 to $600 \mathrm{MPa}$ but it didn't exceed $700 \mathrm{MPa}$. After that the pill was kept in the press for $30-50 \mathrm{~min}$. We have got series of typical SEM images containing somewhere about 500-1200 spherical particles, represented on Fig. 1. Analyzing SEM images we have got differential distribution curves of nanoparticle sizes. Apart from distribution diagrams polydispersion systems could be described with the following parameters: number-average diameter $\bar{D}_{n}$, surface-average diameter $\bar{D}_{s}$, volume-average diameter $\bar{D}_{v}$ and polydispersion coefficient $K$

$$
\begin{gathered}
\bar{D}_{n}=\frac{\sum D_{i} n_{i}}{\sum n_{i}}, \bar{D}_{s}=\frac{\sum n_{i} D_{i}^{3}}{\sum n_{i} D_{i}^{2}}, \\
\overline{\mathrm{D}}_{\mathrm{v}}=\left(\frac{\sum \mathrm{n}_{\mathrm{i}} \mathrm{D}_{\mathrm{i}}^{6}}{\sum \mathrm{n}_{\mathrm{i}} \mathrm{D}_{\mathrm{i}}^{3}}\right)^{1 / 3}, K=\bar{D}_{n} / \bar{D}_{v},
\end{gathered}
$$

where $n_{i}$ - the number of globule fractions with average diameter. The results are represented in Table 1. 


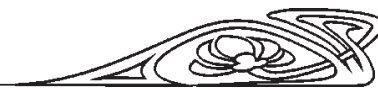

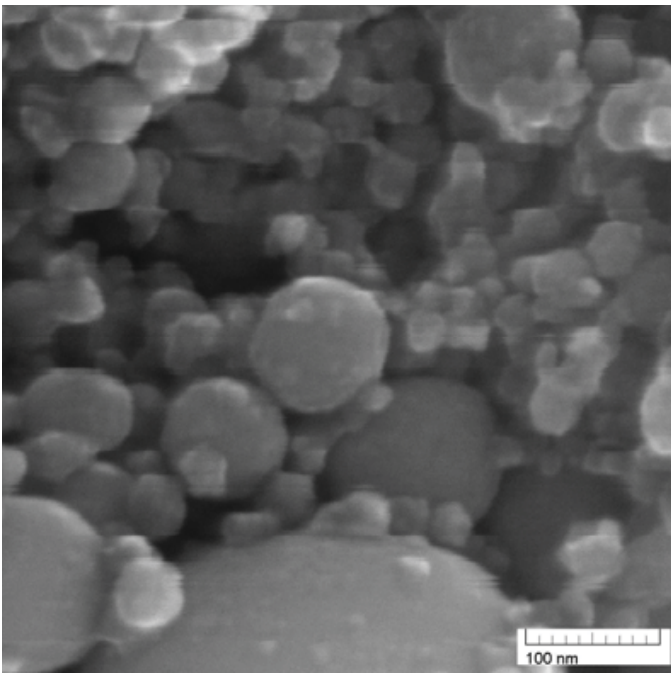

$a$

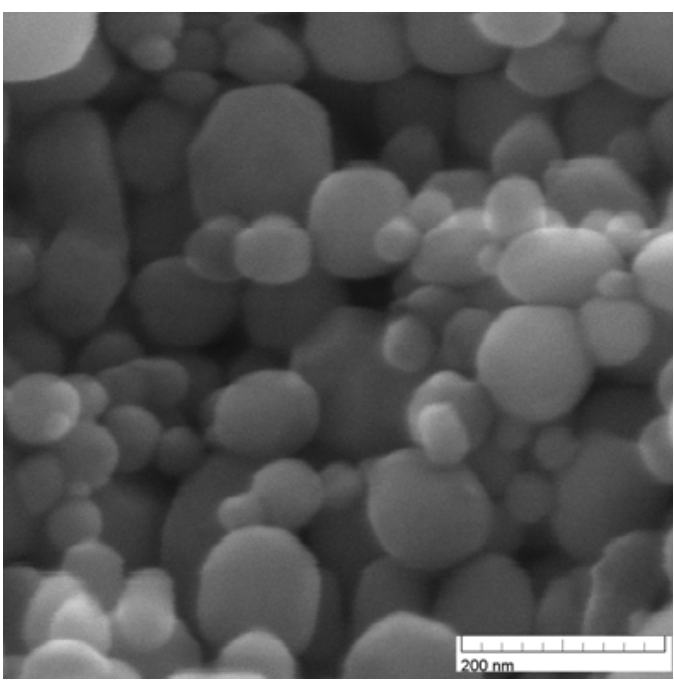

$b$

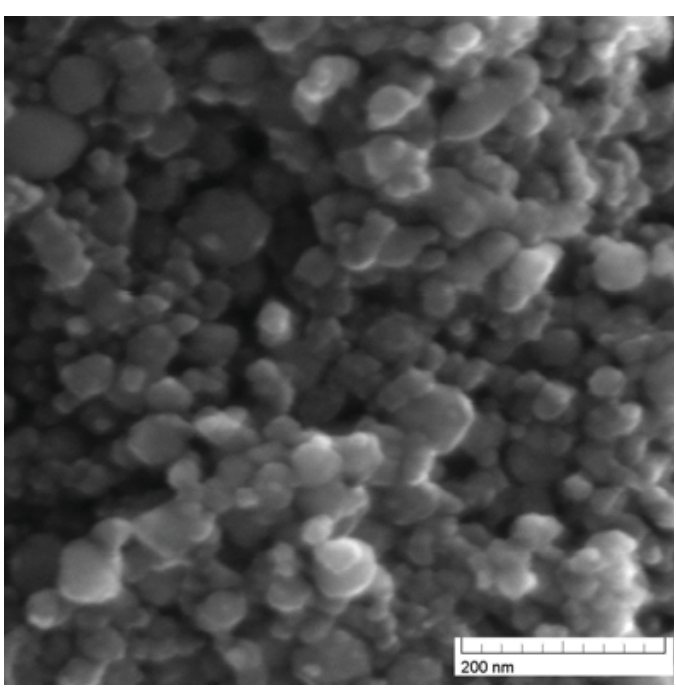

c

Fig. 1. SEM images of nanopowders $\mathrm{SSA}=15 \mathrm{~m}^{2} / \mathrm{gm}(a)$, $\mathrm{SSA}=15.3 \mathrm{~m}^{2} / \mathrm{gm}(b), \mathrm{SSA}=100 \mathrm{~m}^{2} / \mathrm{gm}(c)$
Table 1

Calculation results

\begin{tabular}{|l|c|c|c|}
\hline \multirow{2}{*}{ Parameters } & \multicolumn{3}{|c|}{$\begin{array}{c}\text { Specific surface area } \\
\text { SSA, } \mathrm{m}^{2} / \mathrm{gm}\end{array}$} \\
\cline { 2 - 4 } & 15 & 15.3 & 100 \\
\hline $\begin{array}{l}\text { SEM number-average diameter } \\
D_{n}, \mathrm{~nm}\end{array}$ & 41.1 & 95.3 & 35.8 \\
\hline $\begin{array}{l}\text { SEM surface-average diameter } \\
D_{S}, \mathrm{~nm}\end{array}$ & 45.3 & 111.2 & 40.0 \\
\hline $\begin{array}{l}\text { SEM volume-average diameter } \\
D_{v}, \mathrm{~nm}\end{array}$ & 56.2 & 144.5 & 43.7 \\
\hline $\mathrm{K}$ & 0.7 & 0.7 & 0.8 \\
\hline $\mathrm{N}_{\mathrm{Fe}} / \mathrm{N}_{\mathrm{O}}$ & 6.14 & 10.49 & 7.14 \\
\hline $\mathrm{ECM} d, \mathrm{nM}$ & 26.95 & 76.72 & 24.90 \\
\hline $\mathrm{PDM} d, \mathrm{nM}$ & 27 & 73.61 & 24 \\
\hline $\mathrm{ECM} l, \mathrm{nM}$ & 7.03 & 9.29 & 5.43 \\
\hline $\mathrm{PDM} l, \mathrm{nM}$ & 7 & 10.84 & 5.9 \\
\hline
\end{tabular}

\section{Elemental composition-based method (ECM)} of determining core-shell parameters

Nanoparticles (NP) can be indicated by a great number of different parameters and the most significant among them is their core-shell structure. Recently, a considerable interest has been drawn to the creation of methods that could provide the ability of reliable and nondestructive detection of the topology of NP [13]. Particularly, the identification of the shell thickness $l$ and core diameter $d$ are of interest. However, they are difficulty determined by the fact that the models of NP are a priori unknown and, moreover, their properties can differ from the properties of a solid material. That is why it seems reasonable to use several independent methods which will permit to confirm the applicability of the proposed model, to check if the findings are reliable and to obtain more specific data in case of need. So this study presents a determination of the oxide layer thickness and the diameter of the core in core-shell iron NP using three independent methods. The first of them is based on elemental composition of NP, the second one relies on NP density and the last is grounded on frequency impedometry.

In the majority of possible cases when the shell is generated due to the oxidation process the usage of EDX analysis data (Fig. 2) permit to find a concentration ratio $N_{\mathrm{Fe}} / N_{\mathrm{O}}$ (for instance, for the iron NP):

$$
d=D\left(A \frac{N_{\mathrm{Fe}}}{N_{\mathrm{O}}}-C\right)^{1 / 3}\left(A \frac{N_{\mathrm{Fe}}}{N_{\mathrm{O}}}+B-C\right)^{-1 / 3},
$$


where $d$ is diameter of the core; $D$ is external diameter of the shell or diameter of nanoparticle; $N_{\mathrm{Fe}}, N_{\mathrm{O}}$ are concentrations iron and oxygen in nanoparticle,
$M_{\mathrm{Fe}}, M_{\mathrm{O}}, M_{\mathrm{FeOx}}$ are molecular weights $\mathrm{Fe}, \mathrm{O}, \mathrm{FeO}$; $\rho_{\mathrm{Fe}}, \rho_{\mathrm{FeO}}$ are densities Fe, FeO. Diameter of nanoparticle $D$ is number-average diameter $\bar{D}_{n}$ from SEM.
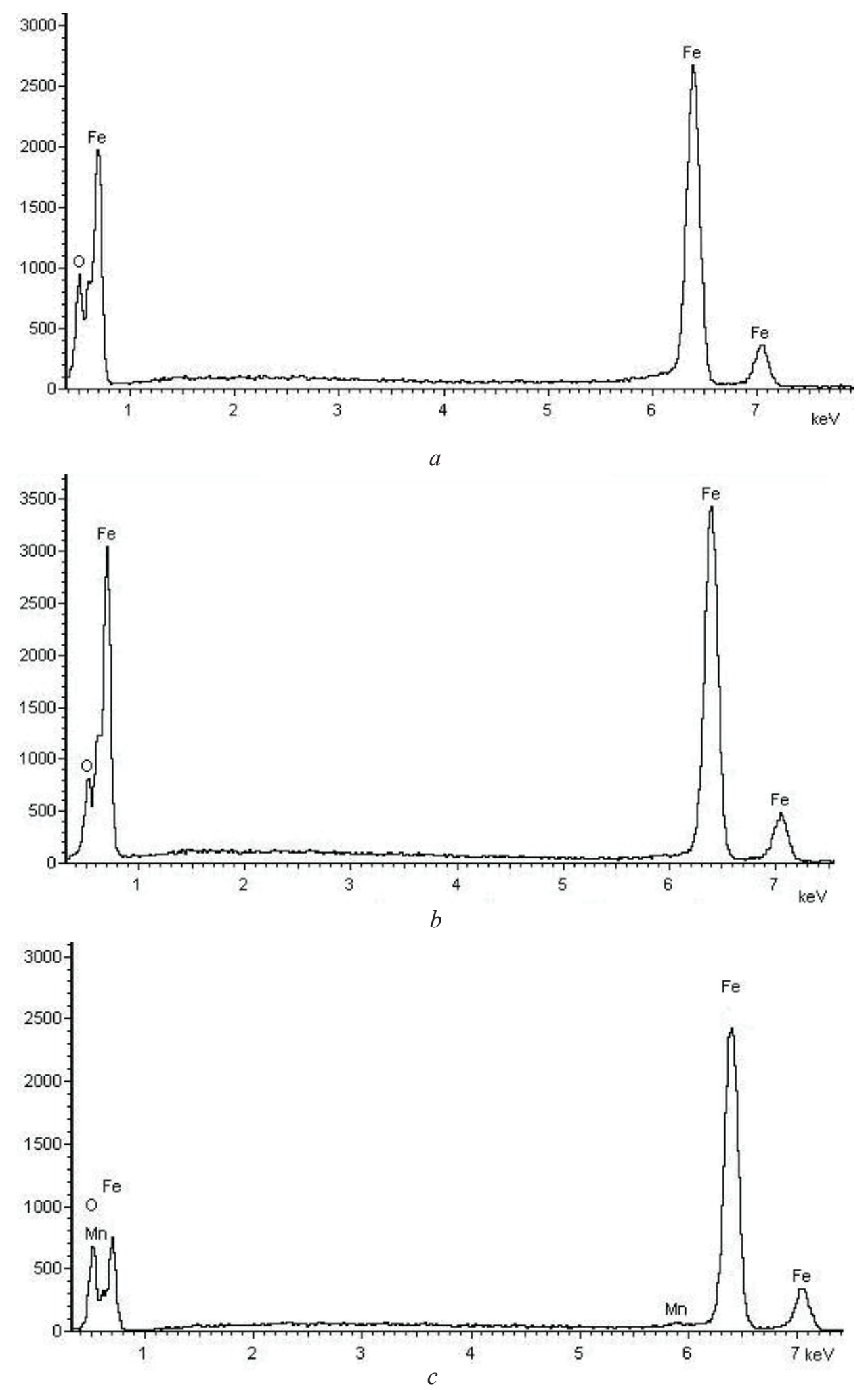

Fig. 2. EDX results of nanopowders: $\mathrm{SSA}=15 \mathrm{~m} 2 / \mathrm{gm}(a), \mathrm{SSA}=15.3 \mathrm{~m} 2 / \mathrm{gm}(b)$, $\mathrm{SSA}=100 \mathrm{~m} 2 / \mathrm{gm}(c)$ 


\section{Particle density-based method (pdm) of determining core-shell parameters}

A single particle density is connected with the values of its sizes by means of the following correlation:

$$
\rho_{\mathrm{NP}}=\frac{\rho_{1} d^{3}+\rho_{2}\left(D^{3}-d^{3}\right)}{d^{3}+\left(D^{3}-d^{3}\right)},
$$

where $\rho_{1}$ and $\rho_{2}$ are the core and the shell densities, respectively. Connecting experimental density $\rho_{\mathrm{e}}$ with referred $\rho$, we have got the expression for the core diameter $d$ :

$$
d=D\left(\frac{\rho_{N P}-\rho_{2}}{\rho_{1}-\rho_{2}}\right),
$$

then thickness of the shell is $l=(D-d) / 2$.

Iron powder samples were investigated using scanning electron microscope (SEM). After respective calculations it was found that the shell thickness $l$ founded with ECM virtually coincide with PDM thickness (Table 1). Calculating error amounts to $1.25 \mathrm{~nm}$, which confirms the validity of the proposed methods.

\section{Frequency impedometry method}

For the realization of this method the formula for the effective permittivity obtained in [14] was applied:

$$
\begin{gathered}
p \alpha \frac{\varepsilon_{2}\left(3 \varepsilon_{1}+(\alpha-1)\left(\varepsilon_{1}+2 \varepsilon_{2}\right)\right)-\varepsilon_{e f f}\left(3 \varepsilon_{2}+(\alpha-1)\left(\varepsilon_{1}+2 \varepsilon_{2}\right)\right)}{2 \varepsilon_{e f f}\left((\alpha-1) \varepsilon_{1}+2(\alpha+1) \varepsilon_{2}\right)+\varepsilon_{2}\left((\alpha+2) \varepsilon_{1}+2(\alpha-1) \varepsilon_{2}\right)}+ \\
+(1-p \alpha) \frac{\varepsilon_{g}-\varepsilon_{e f f}}{\varepsilon_{g}+2 \varepsilon_{e f f}}=0,
\end{gathered}
$$

where $\alpha=D^{3} d^{-3}, \varepsilon_{1}$ is the effective permittivity of metallic core, $\varepsilon_{2}$ is the effective permittivity of the shell, $\varepsilon_{e f f}$ is the permittivity of composite medium, $p$ is the volume fraction of metal in the effective medium, $\varepsilon_{\mathrm{g}}$ is the permittivity of paraffin. In our experiment the iron spherical core-shell particles were randomly distributed in a dielectric matrix paraffin. Firstly, $10 \%$ and then $20 \%$ of composite was located between two glass slices covered with the conductive layer of InxSnyOz. This set up was fulfilles the role of the capacitor.

We investigated frequency dependence of dielectric loss tangent and capacity of composite medium on the precision analyzer components WK 6440B (frequency range $20 \mathrm{~Hz}-3 \mathrm{MHz}$ ). Special shielded container was used to reduce electromagnetic distortions. Dielectric loss tangent and capacity error was not less than $0.2 \%$. We determined fre- quency dependences of real and imaginary dielectric permittivity and conductivity on the base of $C(\omega)$ and $\operatorname{tg} \delta(\omega)$ frequency dependences of investigated composites $\left(C=\varepsilon^{\prime} \varepsilon_{0} S / h, \operatorname{tg} \delta=\varepsilon^{\prime \prime} / \varepsilon^{\prime}\right.$, where $\varepsilon^{\prime}$ is a real part complex dielectric permittivity of nanocomposite; $\varepsilon_{0}$ - permittivity of vacuum, $S$ is sample's area, $h$ is the thickness of nanocomposite layer, $\varepsilon^{\prime \prime}$ is an imaginary part complex dielectric permittivity of nanocomposite).

A special computer program was designed for solving the direct problem - to permit modeling of $\varepsilon^{\prime}$ and $\varepsilon^{\prime \prime}$ frequency dependences subjected to the quantity of frequency dependences of NP conductivity, core-shell parameters, their volume fraction in composite and the properties of matrix material. As a result of modeling it was determined that real and imaginary parts of the complex permittivity of composite media depend on the shell thickness. For instance, the variation of the thickness within 0,5 and $4 \mathrm{~nm}$ produces changes of the real part from 100 to 20 (Fig. 3). The dependences of $\varepsilon^{\prime}$ and $\varepsilon^{\prime \prime}$ on $z$ and on $l$ are essentially different over a various range of values $z$. Such relations make it possible to determine the parameters of NP as their thickness $l$, conductivity $\sigma$ and its frequency dependence (Fig. 4).

Experimentally obtained frequency dependences of complex dielectric permeability components were the basis for solving the inverse problem definition of NP properties. The parameters of NP were processed with a specially created computer program. NP frequency dependence conductivity was assigned as $\sigma=\sigma_{o} \omega^{n}$. Sought quantities $\sigma_{o}, n$ и $l$ were varied up to the best coincidence between rated and experimental dependences $\varepsilon(\omega)$.

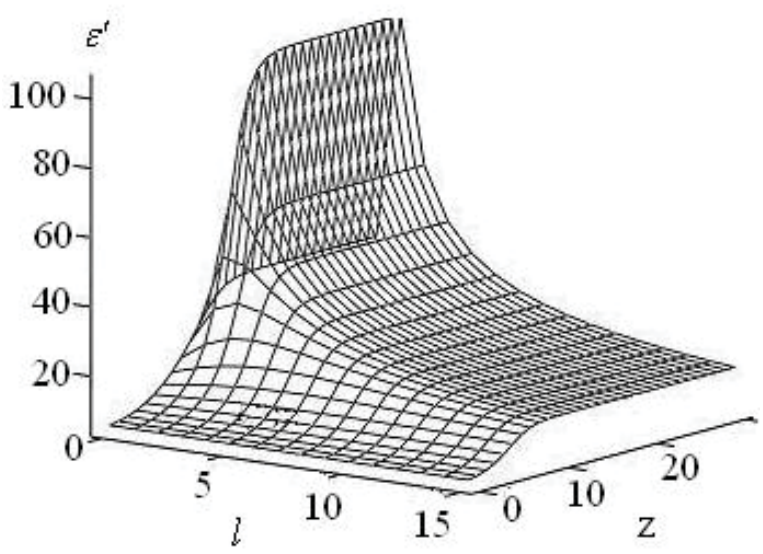

Fig. 3. The dependence of $\varepsilon^{\prime}$ from the shell thickness $1(\mathrm{~nm})$ and $z(z=\sigma / \omega)$ 


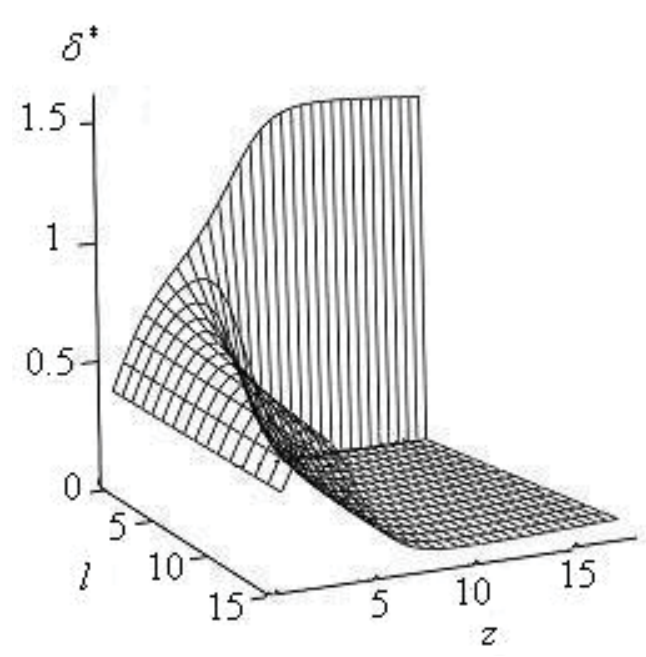

Fig. 4. The dependence of $\delta^{*}=\operatorname{arctg}\left(\varepsilon^{\prime \prime} / \varepsilon^{\prime}\right)$ from the shell thickness $l(\mathrm{~nm})$ and $z(z=\sigma / \omega)$

The approximating line was drawn and the slope of this line $\mathrm{n}$ was determined (Table 2) to on the base plot of the conductivity-frequency of NP. We investigated composites with various volume fraction of nanoparticles $-q$. The coincidence of values $\sigma_{0}$ and $n$ of samples with various volume fraction $q$ confirme the correctness of simulated results. The same value of $\mathrm{n}$ was predicted by [15].

Table 2

Inverse problem solving results

\begin{tabular}{|c|c|c|}
\hline$q$ & $n$ & $\sigma_{\mathrm{o}},(\mathrm{Om} \cdot \mathrm{m})^{-1}$ \\
\hline 0.1 & 1.99 & $4.63 \cdot 10^{-18}$ \\
\hline 0.2 & 2.16 & $5.15 \cdot 10^{-19}$ \\
\hline
\end{tabular}

It was found that the conductivity of NP changed under the following law $\sigma=\sigma_{0} \omega^{2}$.

The methods suggested in the work supplement each other. The most informative is the method which permits to receive the data not only about the interior sizes of NP, but also about a number of physical properties of particles, their dependence on frequency and changes produced by various influences. Such the results can be obtained only by using the measurements of the impedance frequency dependences. More simple methods based on the elemental structure of NP and their density can serve for the data acquisition. These data facilitate appreciably the inverse solution of the multiparameter analysis based on the frequency dependence of complex permittivity.

\section{Conclusion}

The complex research of iron nanoparticles properties by ECM, SEM and PDM methods, supplemented each other, permit to receive the data about the interior sizes of NP, a number of physical properties of particles, their dependence on frequency and changes produced by various influences. It was found that the conductivity of NP changed under the square dependence $\sim \omega^{2}$.

This work was performed as part of the state task of the Ministry of Education and Science of the Russian Federation. Project №3468: Phase and structural modification of micro- and nanostructures by electromagnetic radiation of a wide range of energies. The registration number 114121550163.

Данная работа выполнена в рамках базовой части государственного задания Министерства образования и науки Российской Федеращии (проект № 3468: Фазовая и структурная модификаиия микро- и наноструктур электромагнитным излучением широкого диапазона энергий; номер регистрачии в ЕГИСУ НИОКР 114121550163).

\section{References}

1. Суздалев И. П. Многофункциональные наноматериалы // Успехи химии. 2009. Т. 78, № 3. С. 266-301.

2. Третьяков Ю. Д., Гудилин Е. А. Основные направления фундаментальных и ориентированных исследований в области наноматериалов // Успехи химии. 2009. Т. 78, № 9. С. 867-887.

3. Колпаков Н. С., Семенов А. А., Шепелев А. А., Бочаров А. В., Девин К. Л. Влияние состава и структуры порошков $\mathrm{Fe}-\mathrm{Co}$ на их магнитные характеристики в СВЧ-диапазоне // Перспективные материалы. 2010. № 1. C. 16-23.

4. Петров А. В., Сафронов А. П., Терзиян Т. В., Бекетов И. В., Кудреватых Н. В. Влияние межфазного взаимодействия магнитных частиц наполнителя и полимерной матрицы на магнитные и механические свойства магнитоэластов // Перспективные материалы. 2010. № 5. С. 63-73.

5. Коваленко Л. В., Фолманис Г. Э., Вавилов Н. С. Биологически активные нанопорошки железа // Перспективные материалы. 2005. № 2. С. 39-43.

6. Арсентьева И. П., Э. Л.Дзидзигури, Захаров Н. Д., Павлов Г. В., Ушаков Б. К., Фолманис Г. Э., Арсентьев $A$. $A$. Закономерности строения и биологической активности нанокристаллических порошков железа // Перспективные материалы. 2004. № 4. С. 64-67.

7. Староверов В. М., Апраскин В. П., Чечепео А. И., Фолманис $Г$. Э. Перспективные органоминеральные композиции с наноразмерным железом для растениеводства // Перспективные материалы. 2008. № 6. С. 60-63.

8. Галанов А. И., Юрмазова Т. А.,. Митькина В. А, Савельева Г. Г., Яворовский Н. А., Лобанова Г. Л. Магнитные наночастицы, получаемые электроимпульсным 
методом, их физико-химические свойства и взаимодействие с доксорубицином и плазмой крови // Перспективные материалы. 2010. № 4. С. 49-55.

9. Глушкова А. В., Радилов А. С., Рембовский В. Р. Нанотехнологии и нанотоксикология - взгляд на проблему // Токсикологический вестник. 2007. № 6. С. 4-6.

10. Морохов И. Д., Петрунин В. И., Трусов Л. И., Петрунин $B . \Phi$. Структура и свойства малых металлических частиц // УФН. 1981. Т. 133, вып. 4. С. 653-692.

11. Нагаев Э. Л. Малые металлические частицы // УФН. 1992. Т. 162, вып. 9. С. 49-124.

12. Губин С. П., Кокшаров Ю. А., Хомутов Г. Б., Юрков Г. Ю. Магнитные наночастицы : методы полу- чения, строение и свойства // Успехи химии. 2004. T. 74, № 6. C. 539-574.

13. Martin J. E., Herzing A. A., Yan W., Li X., Koel B. E., Kiely $C$. J., Zhang $W$. Determination of the oxide layer thickness in core-shell zerovalent iron nanoparticles. Langmuir, 2008. Vol. 24, iss. 8. P. 4329-4334.

14. Buchelnikov V. D., Louzguine-Luzgin D. V., Xie G., Li S., Yoshikawa N., Sato M., Anzulevich A. P., Bychkov I. V., Inoue A. Heating of metallic powders by microwaves : experiment and theory // J. App. Phys. 2008. Vol. 104. P. 113505-1-113505-10.

15. Ландау Л. Д., Лифиии Е. М. Электродинамика сплошных сред. М. : Наука, 1982. 624 с.

\section{МИКРОПОЛОСКОВАЯ ЛИНИЯ”

\author{
Д. В. Воронин, Е. Н. Бегинин \\ Саратовский государственный университет \\ E-mail: denis.v.voronin@gmail.com
}

СПЕКТРЫ ПОГЛОЩЕНИЯ И РЕЗОНАНСНЫЕ ЧАСТОТЫ СТРУКТУРЫ «МАГНИТНОЕ НАНОКОМПОЗИТНОЕ ПОКРЫТИЕ -

В работе проведены результаты исследования спектров поглощения СВЧ-мощности в структуре «магнитное нанокомпозитное покрытие - микрополосковая линия», содержащей наночастицы магнетита $\mathrm{Fe}_{3} \mathrm{O}_{4}$. По полученным спектрам поглощения определены характерные для структуры резонансные частоты, соответствующие максимуму поглощения СВЧ-мощности, и рассчитаны материальные параметры нанокомпозитного покрытия: эффективная намагниченность, объемная фракция и поле магнитной кристаллографической анизотропии магнитных наночастиц в покрытии. Полученные в работе результаты могут быть использованы при создании магнитных материалов, содержащих наноразмерные (порядка нескольких десятков нанометров) частицы магнетита, для приборов и устройств, работающих в СВЧ-диапазоне радиоволн.

Ключевые слова: наночастицы магнетита, магнитные нанокомпозитные покрытия, поглощение СВЧ, микрополосковая линия передачи.

\section{Microwave Absorption Spectra and Resonance Frequencies of a «Magnetic Nanocomposite Coating - Microstrip Line" Structure}

\section{V. Voronin, E. N. Beginin}

This paper aims to look into microwave absorption spectra of «magnetic nanocomposite coating - microstrip line» structure, containing magnetite $\mathrm{Fe}_{3} \mathrm{O}_{4}$ nanoparticles. The resulted spectra allowed to define the specific resonance frequencies of the structure under investigation and to figure out the material parameters of the nanocomposite coating, that are, an effective magnetization, a volume fraction of

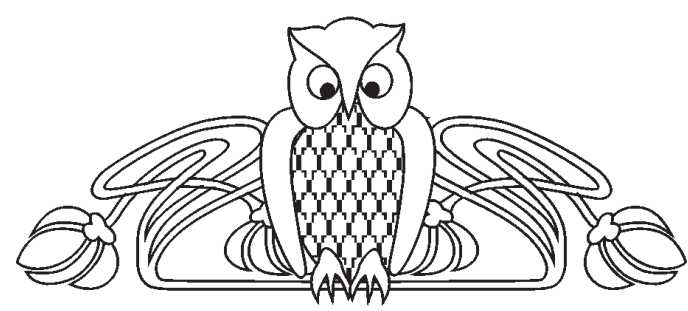

magnetic nanoparticles in the coating as well as a magnetic crystalline anisotropy filed. The results of this work may be used to design new magnetic materials containing magnetite nanoparticles for novel microwave devices with enhanced properties.

Key words: magnetite nanoparticles, magnetic nanocomposites, microwave absorption, microstrip line.

Магнитные нанокомпозитные структуры, представляющие собой дисперсные магнитные наноразмерные частицы, включенные в диэлектрические матрицы, являются перспективными средами для создания новых СВЧ-устройств [1, 2]. Высокочастотными свойствами таких материалов можно управлять в широких пределах, варьируя величину внешнего магнитного поля, геометрические размеры и материальные параметры покрытий (концентрация магнитных частиц, намагниченность, поле анизотропии) [3, 4]. Поэтому важной задачей является определение резонансных частот магнитных возбуждений и материальных параметров нанокомпозитных структур в СВЧ-диапазоне радиоволн. В данной работе приведены результаты исследования спектров поглощения СВЧ-мощности в структуре «магнитное нанокомпозитное покрытие микрополосковая СВЧ-линия передачи» (МПЛ). Использование МПЛ дает преимущество по 